\title{
The Impact of Information Technology on Financial Statement Quality: A Moderating Role of Internal Control System
}

\author{
Dewi Kusuma Wardani ${ }^{1 *}$, Simon Pulung Nugroho ${ }^{2}$ \\ d3wi_kusuma@yahoo.co.id ${ }^{1}$, simon.pulung@upnvyk.ac.id ${ }^{2}$ \\ Universitas Sarjanawiyata Tamansiswa, Yogyakarta, Indonesia ${ }^{1}$ \\ Universitas Pembangunan Nasional "Veteran", Yogyakarta, Indonesia²
}

\begin{abstract}
Information technology contributes to business efficiency, including the improvement of financial statement quality. This study aims to determine the impact of information technology on the financial statements quality and the moderating effect of the internal control system. The study used sixty village-owned enterprises in Kulon Progo, with 120 respondents. Using moderated regression analysis (MRA), the result showed that information technology affected financial statement quality. The internal control system strengthened the impact of information technology on financial statement quality. The result implies that village-owned enterprises must use information technology to improve their financial statement quality. Furthermore, the internal control system must be well implemented to make sure that the information technology can minimize errors and improve the quality of the financial statement.
\end{abstract}

Keywords: information technology, financial statement quality, internal control system

\section{Introduction}

Law Number 32/2004 mandates the government to the established village-owned enterprise, by the village's needs and potentials [1]. The purpose of its establishment is to empower and to increase the village's possibilities. The initial capital of village-owned enterprise source is local revenue and budgeting. Further, its money may come from village funding, community savings, grants, loan, or business cooperation with other parties [2].

The village-owned enterprise consists of business units with legal entities. For accountability, village-owned enterprise makes a monthly financial statement for all of their business units. The financial report is the accountability form to internal stakeholders (manager and board of commissioners) and external stakeholders (government, banks, owners, and tax officers). Because financial statement influences the decision quality, it must be qualified [3], [4]. The qualified financial statement should meet the qualitative characteristics, i.e., relevant, reliable, comparable, and understandable [5]. The quality of financial statements will improve the quality of the information presented in the financial statements. Users are confident in making decisions because they use data that well-prepared, approved, and audited [6].

Yogyakarta has 156 village-owned enterprises, with $41.67 \%$ in Kulon Progo. Villageowned in Kulon Progo is transferring status from village microfinance institution. Because of every village in Kulon Progo has microfinance institution, that basically, all microfinance institution changes their state to the village-owned enterprise, so every town in Kulon Progo has 
village-owned enterprises. In an interview, the economic section of the regent's office (May 4, 2017) said the general problem that occurred in Kulonprogro village-owned enterprise lies in the human resource and financial statement quality. Village-owned enterprise's human resources are not experts. They do not have the skill to make a financial statement. They do not understand how to make proper and correct financial statement, so the financial account is still relatively simple and often not on time.

One factor that influences financial statement quality is information technology [6]-[11]. Utilization of information technology in financial data management provides benefits from accuracy and flexibility in financial statement preparation [11]. By utilizing information technology, the accuracy of the financial data will improve. The errors that occur can be minimized with information technology. The financial statement can be served on time because information technology helps speed up the transaction data processing. Management is easy to prepare financial statement [7]. So the financial statement can ready on time and does not lose its quality, i.e., timeliness. Researchers find that information technology will improve financial statement quality[6]. In another hand, another researcher cannot find the impact of information technology on financial statement quality and others find that information technology has a negative impact on financial statement quality [12]. That contrary results lead question on what conditions information technology can improve the financial statement quality. The first hypothesis is Information technology improves financial statement quality.

The internal control system can improve the impact of information technology on financial statement quality [13]. Internal control is a method to direct, monitor, and measure the human resources that involved in the organization [14]. Management can control the organization with the internal control system. They can direct, control, and measure human resources to make organization efficiency. Internal control can detect and prevent fraud [15], [16]. Management can minimize recording and calculation errors [17]. In computerized environments, management must conduct internal control to avoid repeating errors. There is a much internal control that conducted in the information technology case [18]. First, updates of the information system in accordance with the legislative change. Second, the user knowledge of computer operation. Third, data access restriction. Fourth, media for backup data. Fifth, detect and resolve errors. With the good internal control, management can ensure that the data generated is completely accurate [16], [19]. So, internal control system improves the positive impact of information technology on financial statement quality. The second hypothesis is the positive impact of information technology on financial statement quality is greater in the villageowned enterprise that has a good internal control system.

This research investigates the impact of information technology on financial statement quality. This research also examines the moderation effect of the internal control system of that effect. The internal control system will improve the impact of information technology on financial statement quality. This research contributes to the literature. First, to our knowledge, this is the first study to document a positive impact of information technology on village-owned financial statement quality, which adds to the recent stream of public accounting research. Second, this research extends the emerging literature of financial statement quality. This research provides new evidence that internal control system can improve the impact of information technology on financial statement quality.

The remainder of the paper is structured as follows. Section 2 research method. Section 3 discusses the results and discussion. Last, chapter 4 presents the conclusions. 


\section{Research Method}

The population is eighty-eight village-owned enterprises in Kulon Progo. With purposive sampling method, this research uses sixty village-owned enterprises, with 120 respondents. The criteria of the respondent are operators or manager that involve on financial statement preparation. The data source is the primary data, with questionnaires as data collection method.

This study uses three variables. Information technology is the independent variable. Financial statement quality is the dependent variable. The internal control system is moderating variable. Information technology is the level of information technology integration on the accounting tasks. It is measured using five indicators, (1) automated work process, (2) processing and storage of financial data, (3) information processing with internet network, (4) management system, and (5) maintenance of computer equipment [15]. The internal control system is an integral process of activities and actions carried out continuously by the leadership and the achievement of organizational goals through effective and efficient operations, the reliability of financial reporting, security of state assets, and compliance with laws and regulations [15], [20]. It is measured using six indicators, (1) adequate design, (2) the use of sufficient documents and records, (3) separation of authority, (4) access restrictions, (5) disciplinary action for violations, and (6) preventive measures and cessation of operations computers [15]. Financial statement quality is the four characters of the financial statement, i.e., relevant, reliable, comparable, and understandable [3]. It is measured using nine indicators, (1) the usefulness of financial statement, (2) the accuracy of financial statements, (3) the completeness of the information presented, (4) the honesty of presentation, (5) the verification of the contents, (6) the neutrality of data, (7) the accuracy of the information presented, (8) the comparability of materials, and (9) the clarity of the presentation [21], [22], [23].

Researchers conduct a pilot test to find out whether the instrument is feasible to use in actual research. Based on validity result, there are thirty-two items that valid, while four elements are not authentic. One indicator, i.e., an internet network, is deleted because of the absence of internet network in the village-owned enterprise. Based on Cronbach alpha, each variable is reliable. This research uses two analysis method. The first hypothesis uses regression analysis. The second hypothesis used moderated regression analysis. Before that, researchers do a classical assumption test, i.e., normality, heteroscedasticity, and multicollinearity, to ensure that the equation is a best linear unbiased estimator.

\section{Results and Discussion}

Because the Pearson-correlation values are above r-table (between $0.256-0.830>0.2039$ ), all items are valid. Because of Cronbach Alpha value higher than 0.006 (i.e., 0.772, 0.788, and $0.901)$, the items are reliable. The data in this study are stated normally distributed. This is indicated by the value Kolmogorov-Smirnov of 0.531 and significance value of 0.940 which means higher than alpha value 0.05 . This research is free from multicollinearity problem. This is evidenced by the tolerance value $>0.10$ and the VIF value $<10$. This study declared escaped the problem of heteroscedasticity. This is supported by the significance value of each variable that is above 0.05 . 
Table 1. Regression of Internal Control System on Information Technology and Financial Statement Quality

\begin{tabular}{llll}
\hline & Model 1 & Model 2 & Model 3 \\
\hline Intercept & 52,769 & 28,997 & 104,615 \\
& $0,000^{* * *}$ & $0,000^{* * *}$ & $0,000^{* * *}$ \\
Information Technology & 1,179 & 0,513 & $-2,818$ \\
& $0,000^{* * *}$ & $0,001^{* * *}$ & $0,011^{* *}$ \\
Internal Control System & & 1,343 & $-1,341$ \\
& & $0,000^{* * *}$ & 0,131 \\
Information Technology*Internal Control System & & & 0,117 \\
Adjusted R square & 0,371 & 0,548 & $0,002^{* * *}$ \\
\hline
\end{tabular}

Table 1 shows the result from estimating model 1, 2, 3. Researchers estimate the model using linear equation model and moderated regression analysis. In model 1 the researcher regress the independent variable, information technology, on the dependent variable. The result shows that information technology has a significant impact on financial statement quality, with considerable value 0.000 . Beta value is 1.179 with positive direction implies that information technology improves financial statement quality. Based on this result, H1 is supported. These results are supported by research which resulted that information technology has a positive impact on the financial statements quality [6], [7],[8], [9], [10], [11]. The result of the research is not supported by the research which stated that the information technology has no effect on the quality of the financial report and also contradicts with a study that finds information technology has an adverse impact on financial statement quality [12].

In model 3, researcher regresses the independent variable, information technology, internal control system, and moderation variable (informational technology*internal control system), on the dependent variable, financial statement quality. The result shows that internal control system improves the positive impact of information technology on financial statement quality, with significant value 0.002 and beta 0.117 . Model 2 shows that internal control system has a positive effect on financial statement quality, with substantial amount 0.000 and beta 1.343 . The result implies that internal control system is quasi-moderation. Thus, it can be concluded that $\mathrm{H} 2$ is supported. The findings are supported by [13] which states that the internal control system can moderate the utilization of information technology on the quality of local government financial statements.

\section{Conclusions}

Data analysis is conducted on respondents that directly involved in village-owned enterprise's financial transactions recording and financial statement preparation in Kulonprogo. The result shows that information technology improves the financial statement quality. The impact of information technology on the financial statement quality is higher in a village-owned enterprise that has good internal control system than a village-owned enterprise that has a bad internal control system. The result implies that village-owned enterprises must use information technology to improve their financial statement quality. Furthermore, they must have a good internal control system to make sure that the information technology can minimize errors and improve the quality of the financial statement. 
This research has several limitations. First, this research conducts in Kulon Progo, so the result cannot be generalized to others. Next analysis should compare district that has good financial statement quality and poor one. Second, this research uses a questionnaire to get data, so the researcher cannot dig deeper. Next research should use another method, to find other factors that influence financial statement quality, like human resource competencies, clarity of rules, and experience.

\section{References}

[1] Indonesian Government, Indonesian Law 32/2004 about Local Government. 2004.

[2] Indonesian Government, Regulation of Home Affairs Minister No. 39/2010 about VillageOwned Enterprise. 2010.

[3] Indonesian Government, Government Regulation no. 71 of 2010 about Government Accounting Standard. 2010.

[4] T. Silalahi and S. Sinambela, "Determinants of Financial Report Accountability, and It'S Implication on Financial Report Quality an Empirical Study of Financial Report Statement in North Sumatra Province, Indonesia," Int. J. Econ. Commer. Manag. United Kingdom, vol. 3, no. 3, pp. 159-172, 2017.

[5] Mardiasmo, Akuntansi Sektor Publik. Yogyakarta: Andi Publisher, 2009.

[6] L. Liyan, "The Impact of Information Technology on Accounting Theory, Accounting Profession, and Chinese Accounting Education Profession, and Chinese Accounting Education," Wuhan Int. Conf. E-bus. 2013 Proc., 2013.

[7] M. H. K. Zadeh, A. Karkon, and H. Golnari, "The Effect of Information Technology on the Quality of Accounting Information system and Its impact on the Quality of Accounting Information," Res. J. Financ. Account., vol. 3, no. 3, pp. 061-076, 2015.

[8] J. M. Medina-Quintero, A. Mora, and D. Abrego, "Enterprise Technology in Support for Accounting Information Systems: An Innovation and Productivity Approach," J. Inf. Syst. Technol. Manag., vol. 12, no. 1, pp. 29-44, 2015.

[9] F. P. C. Lim, "Impact of Information Technology on Accounting Systems," Asia-pacific J. Multimed. Serv. Converg. with Art, Humanit. Sociol., vol. 3, no. 2, pp. 93-106, 2013.

[10] Bakri, "Effect of the Use of Information Technology and Organization Cultural of the Quality Accounting Information System,” Internatioal J. Sci. Tecnol. Res., vol. 5, no. 04, pp. 120-125, 2016.

[11] M. I. Sačer and A. Oluić, "Information Technology and Accounting Information Systems' Quality in Croatian Middle and Large Companies," J. Inf. Organ. Sci., vol. 37, no. 2, pp. $117-$ 126, 2013.

[12] Nurlis and W. Yadiati, "The Influence of Internal Control Effectiveness, Information Technology Utilization and Human Resources Competence on Local Government Financial Reporting Quality ( Survey on SKPD Banten Provincial Government and Serang City ), Res. J. Financ. Account., vol. 8, no. 12, pp. 111-124, 2017.

[13] Fitriana and A. Wahyudin, "Factors Influencing The Quality of Financial Reporting on Local Government of Purbalingga," Account. Anal. J., vol. 6, no. 1, pp. 27-38, 2017.

[14] S. Desimone, "Internal Audit and Financial Reporting Quality in the Public Sector," Work. Pap. Coll. Holy Cross, no. July, 2017.

[15] D. K. Wardani and I. Andriyani, "Pengaruh Kualitas Sumber Daya Manusia, Pemanfaatan Teknologi Informasi, Dan Sistem Pengendalian Intern Terhadap Keandalan Pelaporan Keuangan Pemerintahan Desa Di Kabupaten Klaten,” J. Akunt., vol. 5, no. 2, pp. 88-98, 2017.

[16] C. L. Kewo and N. N. Afiah, "International Journal of Economics and Financial Issues Does Quality of Financial Statement Affected by Internal Control System and Internal Audit?," Int. J. Econ. Financ. Issues, vol. 7, no. 2, pp. 568-573, 2017.

[17] E. Y. Kasim, "Effect of Government Accountants Competency and Implementation of Internal 
Control to the Quality of Government Financial Reporting," Int. J. Business, Econ. Law, vol. 8, no. 1, pp. 97-105, 2015.

[18] N. Mahzan and F. Veerankutty, "IT Auditing Activities of Public Sector Auditors in Malaysia," African J. Bus. Manag., vol. 5, no. 5, pp. 1551-1563, 2011.

[19] N. N. Afiah and D. N. Rahmatika, "The Impact of Internal Audit Function Effectiveness on Quality of Financial Reporting and its Implications on Good Government Governance Research on Local Government Indonesia," Int. J. Business, Econ. Law, vol. 5, no. 1, pp. 64-75, 2014.

[20] Indonesian Government, Government Regulation No. 60/2008 about Government Internal Control Standard. 2008.

[21] F. Van Beest, G. Braam, and S. Boelens, "Quality of Financial Reporting : Measuring Qualitative Characteristics," NiCE Work. Pap. 09-108, no. April, pp. 1-41, 2009.

[22] M. Salehi and E. Torabi, "The Role of Information Technology in Financial Reporting Quality: Iranian Scenario," Posl. Izvr. Zagreb, vol. 6, no. 1, pp. 115-128, 2012

[23] K. S. Herath and N. Albarqi, "Financial Reporting Quality: A Literature Review," Int. J. Bus. Manag. Commer., vol. 2, no. 2, pp. 1-14, 2017. 